\title{
INTEGRASI CONTEXTUAL TEACHING LEARNING (CTL) DENGAN GEOGEBRA: DAPATKAH MENINGKATKAN KEMAMPUAN KONEKSI MATEMATIS SISWA?
}

\author{
Yanti Nurhayati' ${ }^{1}$, Nur Eva Zakiah², Asep Amam ${ }^{3}$ \\ 1,2,3 Universitas Galuh, Jl. R. E Martadinata No. 150, Ciamis, Indonesia \\ Email: mathstudentunigal@gmail.com
}

\begin{abstract}
The problem in this study is the ability of students' mathematical connections are still relatively low. Based on a literature review and relevant research that uses Contextual Learning Teaching (CTL) assisted by geogebra software. The aim of this study is to comprehensively examine the improvement of students' mathematical connection abilities using CTL learning assisted by geogebra software better than students who use conventional learning. The research method uses a quasi experiment with a non-equivalent pretest-posttest control group design. The data analysis technique used independent sample t-test. The study population was all eighth grade students of MTs Negeri 1 Ciamis consisting of six classes, with a sampling technique using purposive sampling. The selected sample were students of class VIII-A totaling 25 people as the experimental class and students of class VIII-B totaling 26 people as the control class. The instrument used was a test of mathematical connection ability in the form of problem descriptions. Data analysis using N-gain data obtained from the results of the pretest and posttest. The results showed that contextual teaching and learning (CTL) learning assisted by geogebra software could be an alternative to improve students' mathematical connection skills for the better.
\end{abstract}

Keywords: Contextual teaching learning, geogebra software, mathematical connection ability

\begin{abstract}
ABSTRAK
Masalah dalam penelitian ini adalah kemampuan koneksi matematis siswa masih tergolong rendah. Berdasarkan kajian literatur dan penelitian yang relevan yaitu pembelajaran Contextual Teaching Learning (CTL) berbantuan software geogebra dapat meningkatkan kemampuan koneksi matematis. Tujuan dari penelitian ini adalah untuk mengkaji secara komprehensif tentang peningkatan kemampuan koneksi matematis siswa menggunakan pembelajaran CTL berbantuan software geogebra lebih baik daripada siswa yang menggunakan pembelajaran konvensional. Metode penelitian menggunakan quasi experiment dengan desain non-equivalent pretest-posttest control group. Teknik analisis data menggunakan independent sample t-test. Populasi penelitian adalah seluruh siswa kelas VIII MTs Negeri 1 Ciamis yang terdiri dari enam kelas, dengan teknik pengambilan sampel menggunakan purposive sampling. Sampel yang terpilih adalah siswa kelas VIII-A berjumlah 25 orang sebagai kelas eksperimen dan siswa kelas VIII-B berjumlah 26 orang sebagai kelas kontrol. Instrumen yang digunakan adalah tes kemampuan koneksi matematis berupa soal uraian. Analisis data menggunakan data $\mathrm{N}$-gain yang diperoleh dari hasil pretes dan postes kemampuan koneksi matematis. Hasil penelitian menunjukkan bahwa pembelajaran Contextual Teaching Learning (CTL) berbantuan software geogebra dapat menjadi alternatif untuk meningkatan kemampuan koneksi matematis siswa menjadi lebih baik.
\end{abstract}

Kata kunci: Pembelajaran contextual teaching learning, software geogebra, kemampuan koneksi matematis

Dikirim: 08 Februari 2020; Diterima: 15 Februari 2020; Dipublikasikan: 30 Maret 2020

Cara sitasi: Nurhayati, Y., Zakiah, N. E., \& Amam, A. (2020). Integrasi contextual teaching learning (ctl) dengan geogebra: dapatkah meningkatkan kemampuan koneksi matematis siswa?. Teorema: Teori dan Riset Matematika, 5(1), 27-34. 


\section{PENDAHULUAN}

Pembelajaran merupakan proses interaksi siswa dengan siswa, siswa dengan guru, serta siswa dengan sumber belajar pada lingkungan belajar. Proses pembelajaran perlu direncanakan, dilaksanakan serta diawasi agar terlaksana secara efektif. Salah satu keberhasilan siswa dalam proses pembelajaran yaitu dapat dilihat dari aspek kognitifnya. Proses belajar siswa hanya akan terjadi jika pengetahuan yang dipelajari bermakna bagi siswa. Suatu pengetahuan akan bermakna bagi siswa ketika siswa dapat mengumpulkan informasi pengetahuan lalu dapat menerapkannya ke dalam kehidupan sehari-hari (Amam, 2017).

Matematika sebagai ilmu terstruktur dimana pembelajaran matematika harus diawali dari yang mudah, sedang, hingga sulit, sebab dalam matematika terdapat konep-konsep yang saling keterkaitan antara yang satu dengan yang lainnya sehingga agar siswa dapat memahami pemahaman konsep secara mendalam maka kemampuan koneksi matematis harus dimiliki oleh siswa. Hal tersebut mengacu pada National Council of Teacher of Mathematics (NCTM) bahwa standar proses dalam pembelajaran matematika yaitu kemampuan pemecahan masalah (problem solving), kemampuan penalaran (reasoning), kemampuan komunikasi (communication), kemampuan membuat koneksi (connection) dan kemampuan representasi (representation) (NCTM, 2000).

Salah satu tujuan pembelajaran matematika berdasarkan Peraturan Menteri Pendidikan dan Kebudayaan Republik Indonesia Nomor 58 tahun 2014 yaitu "Memahami konsep matematika merupakan kompetensi dalam menjelaskan keterkaitan antar konsep dan menggunakan konsep maupun algoritma, secara luwes, akurat, efisien dan tepat dalam pemecahan masalah". Berdasarkan hal tersebut kemampuan koneksi matematis merupakan salah satu dari kemampuan yang perlu dimiliki serta dikembangkan pada siswa, karena indikator kemampuan koneksi matematis akan membantu siswa untuk mencapai tujuan pembelajaran.

NCTM (2000) menyatakan kemampuan koneksi matematis merupakan kemampuan siswa dalam menghubungkan antar konsep matematika, serta menerapkan matematika di luar konteks matematika. Hubungan-hubungan dalam matematika tersebut tidak hanya membuat siswa belajar secara teoritis tetapi juga belajar tentang manfaat matematika guna menghubungkannya dengan bidang lain atau dalam kehidupan sehari-hari. Apabila siswa mampu memahami serta mengaitkan antar konsep matematika maka pemahaman konsep yang dimiliki siswa akan lebih dalam serta bertahan lama. Hal tersebut akan membuat siswa mengenali banyak hubungan antar konsep matematika, bidang lain serta pada pengalamannya sendiri dalam kehidupan sehari-hari.

Hasil observasi yang telah dilakukan di salah satu MTs Negeri Kabupaten Ciamis, diperoleh data dari satu kelas yang diamati bahwa $26,92 \%$ siswa dapat mengerjakan soal tes kemampuan koneksi matematis. Hal ini diperkuat dengan hasil wawancara yang menyatakan bahwa siswa dapat menyelesaikan soal matematika secara langsung dengan penerapan rumus-rumus matematika. Namun dalam hal ini siswa masih belum mampu menyelesaikan soal-soal yang ada kaitannya dengan kehidupan sehari-hari. Oleh sebab itu siswa masih bingung jika ditanya manfaat dari materi yang telah disampaikan. Hal tersebut memberikan gambaran bahwa siswa masih belum mampu menghubungkan ide-ide antar topik matematika dalam penyelesaian masalah yang berkaitan dengan kehidupan sehari-hari. Kemampuan dalam menghubungkan ide-ide antar topik matematika serta menerapkannya ke dalam kehidupan sehari-hari merupakan kemampuan koneksi matematis. Dengan demikian kemampuan koneksi matematis tersebut masih perlu ditingkatkan.

Kemampuan koneksi matematis erat kaitanya dengan masalah kontekstual, sebab koneksi membutuhkan sebuah kontek untuk menghubungkanya. Nurhadi (Rusman, 2017) menyatakan bahwa pembelajaran kontekstual merupakan konsep belajar yang dapat membantu guru mengaitkan antara materi yang diajarkan serta membuat hubungan antar pengetahuan yang dimiliki siswa dengan penerapannya ke dalam kehidupan sehari-hari. Kegiatan pembelajaran yang mengkoneksikan materi pelajaran dengan konteks kehidupan akan mampu membiasakan siswa melakukan proses 
perencanaan pemecahan masalah, menyelesaikan perhitungan, melakukan pengawasan proses pemecahan masalah, dan melakukan evaluasi hasil pemecahan masalah (Zakiah et.al, 2019).

Bukti lain eratnya kaitan antara kontekstual dengan CTL adalah penelitian Musriliani et.al (2015) menyatakan bahwa Contextual Teaching Learning (CTL) memberikan pengaruh terhadap kemampuan koneksi matematis siswa smp ditinjau dari gender. Implementasi pembelajaran kontekstual telah dilakukan oleh berbagai peneliti. Zakiah (2017) menyatakan bahwa pendekatan kontekstual berbasis gaya kognitif mampu meningkatkan kemampuan metakognitif siswa. Selanjutnya hasil penelitian Sunaryo \& Fatimah (2019) bahwa pendekatan kontekstual pada model pembelajaran scaffolding dapat meningkatkan kemampuan berpikir kritis matematik. Hal tersebut menunjukkan bahwa pembelajaran kontekstual memberikan efek baik pada berbagai kemampuan matematis siswa.

Salah satu ciri bahwa siswa memiliki kemampuan koneksi matematis yaitu siswa dapat mengenali dan menggunakan hubungan antar ide matematika serta dapat menerapkannya dalam kehidupan sehari-hari. Software geogebra dapat dijadikan sebagai media dalam membantu siswa menghubungkan ide-ide matematika. Hal ini karena software geogebra dapat memvisualisasikan aljabar, geometri dan kalkulus selain itu menjadikan konsep matematika yang rumit menjadi lebih sederhana sehingga dapat membantu siswa mengkontruksi pengetahuannya dari bentuk visualisasi dan mengarahkan siswa pada kemampuan pemahaman konsep secara mendalam yang akan membantu siswa untuk dapat mengaitkan konsep tersebut dengan bidang lain diluar topik matematika atau dengan kehidupan nyata (Amam et.al, 2017).

Berdasarkan masalah yang telah dipaparkan, tujuan penelitian ini adalah untuk mengkaji secara komprehensif tentang peningkatan kemampuan koneksi matematis siswa dengan menggunakan pembelajaran CTL berbantuan software geogebra.

\section{METODE PENELITIAN}

Metode penelitian yang digunakan adalah quasi experiment atau disebut juga eksperimen semu. Desain dalam penelitian ini menggunakan nonequivalent control group yang digambarkan sebagai berikut.

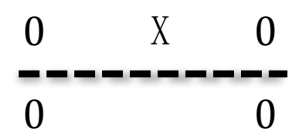

\section{Gambar 1. Nonequivalent control group desain}

Keterangan:

$\mathrm{X}$ : Perlakuan atau treatment dengan pembelajaran CTL berbantuan software geogebra

0 : Pretes atau postes kemampuan koneksi matematis

--- : Subjek tidak dipilih secara acak

Populasi penelitian ini adalah seluruh siswa kelas VIII di MTs Negeri 1 Ciamis Tahun Pelajaran 2017/2018 yang terdiri dari enam kelas. Kelas VIII dipilih karena lemahnya kemampuan koneksi matematis siswa mendominasi pada tingkatan ini. Pengambilan sampel menggunakan teknik purposive sampling yaitu pengambilan sampel berdasarkan pertimbangan tertentu, terpilih kelas VIII A sebagai kelas eksperimen dan kelas VIII B sebagai kelas kontrol. Kedua kelas tersebut memiliki kemampuan yang hampir sama. Instrumen yang digunakan dalam penelitian ini adalah instrumen tes berupa soal uraian sebanyak 3 butir.

Prosedur penelitian ini meliputi empat tahap, diantaranya: (1) tahap persiapan; (2) tahap pelaksanaan; (3) tahap analisis data; dan (4) tahap penarikan kesimpulan. Pada tahap persiapan penelitian, kegiatan yang dilakukan antara lain: melakukan observasi ke sekolah, membuat instrumen tes yaitu soal kemampuan koneksi matematis berupa soal uraian dan instrumen pembelajaran yaitu RPP untuk kelas eksperimen dan kelas kontrol. Setelah menyusun instrumen tes kemampuan koneksi 
matematis berdasarkan indikator kemampuan koneksi matematis selanjutnya intrumen tes diujicobakan pada siswa yang pernah mendapat pembelajaran mengenai materi tersebut. Setelah itu peneliti melakukan analisis hasil uji coba tersebut dengan menggunakan uji validitas, reliabilitas, daya beda serta indeks kesukaran yang bertujuan untuk mengetahui kelayakan instrumen tes yang akan digunakan untuk penelitian. Berdasarkan hasil uji coba dipilih tiga butir soal yang telah memenuhi kriteria soal yang baik untuk dijadikan sebagai alat ukur kemampuan koneksi matematis.

Tahap pelaksanaan penelitian, kegiatan yang dilakukan antara lain: memberikan pretes pada kelas eksperimen dan kelas kontrol, dilanjutkan dengan memberikan treatment kepada kedua kelas yaitu pembelajaran CTL berbantuan software geogebra pada kelas eksperimen dan pembelajaran konvensional pada kelas control, kemudian memberikan postes pada kedua kelas.

Tahap analisis data, kegiatan yang dilakukan antara lain: mengolah data hasil penelitian dengan teknik statistik kuantitatif. Data yang dianalisis adalah data pretes dan $\mathrm{N}$-gain menggunakan uji normalitas, uji homogenitas dan uji perbedaan dua rerata. Selanjutnya menginterpretasi hasil pengolahan data. Tahap terakhir yaitu penarikan kesimpulan dari pengolahan data hasil prestes dan $\mathrm{N}$-gain untuk menjawab rumusan masalah dalam penelitian ini.

\section{HASIL DAN PEMBAHASAN}

Data penelitian diperoleh dari hasil skor pretes dan $\mathrm{N}$-gain kelas eksperimen yang menggunakan pembelajaran contextual teaching and learning (CTL) berbantuan software geogebra dan kelas kontrol menggunakan pembelajaran konvensional disajikan dalam bentuk tabel. Tabel 1 merupakan rangkuman statistika deskriptif data hasil pretes dan $\mathrm{N}$-gain untuk kedua kelas.

Tabel 1.

Statistika deskriptif kemampuan koneksi matematis siswa

\begin{tabular}{|c|c|c|c|}
\hline \multicolumn{2}{|c|}{ Kelas } & Eksperimen & Kontrol \\
\hline \multicolumn{2}{|c|}{$\mathrm{N}$} & 25 & 26 \\
\hline & $\bar{x}$ & 2,48 & 2,76 \\
\hline \multirow[t]{3}{*}{ Pretes } & $x_{\min }$ & 0 & 1 \\
\hline & $x_{\text {maks }}$ & 5 & 5 \\
\hline & $\bar{x}$ & 0,83 & 0,66 \\
\hline \multirow[t]{2}{*}{$N$ gain } & $x_{\min }$ & 0,43 & 0,33 \\
\hline & $x_{\text {maks }}$ & 1,00 & 1,00 \\
\hline
\end{tabular}

Berdasarkan Tabel 1 diperoleh skor rata-rata $(\bar{x})$ pretes untuk kelas eksperimen yang menggunakan pembelajaran CTL berbantuan software geogebra adalah 2,48 dan skor rata-rata $(\bar{x})$ pretes kelas kontrol adalah 2,76, selisih antara keduanya adalah 0,28 . Hal tersebut menunjukkan bahwa tidak terdapat perbedaan yang signifikan dari kedua kelas tersebut. Skor rata-rata $(\bar{x}) \mathrm{N}$-gain untuk kelas eksperimen yang menggunakan pembelajaran CTL berbantuan software geogebra adalah 0,83 dan skor rata-rata $(\bar{x}) \mathrm{N}$-gain untuk kelas kontrol yang menggunakan pembelajaran konvensional adalah 0,66 . Hal tersebut menunjukkan bahwa terdapat perbedaan yang signifikan antara kelas eksperimen dan kelas kontrol, yang berarti bahwa peningkatan kemampuan koneksi matematis siswa yang menggunakan pembelajaran CTL berbantuan software geogebra lebih besar dibandingkan dengan kelas yang menggunakan pembelajaran konvensional.

\section{Pretes Kemampuan Koneksi Matematis}

Data pretes kemampuan koneksi matematis siswa kelas ekspreimen dan kelas kontrol dirangkum dalam Tabel 2, disajikan sebagai berikut.

\section{Tabel 2.}

Deskripsi data pretes kemampuan koneksi matematis

\begin{tabular}{ccccc}
\hline Kelas & $\mathbf{N}$ & Rata-rata & Maks & Min \\
\hline Eksperimen & 25 & 2,48 & 5 & 0 \\
Kontrol & 26 & 2,76 & 5 & 1 \\
\hline
\end{tabular}


Selain menggunakan statistik deskriptif, pengolahan data pretes juga dilakukan menggunakan statistik inferensial. Hipotesis yang digunakan adalah:

$$
\begin{aligned}
& H_{0}: \mu_{1}=\mu_{2} \quad \text { Tidak terdapat perbedaan kemampuan awal koneksi matematis siswa antara } \\
& \text { yang menggunakan pembelajaran contextual teaching and learning (CTL) } \\
& \text { berbantuan software geogebra dengan yang menggunakan pembelajaran } \\
& \text { konvensional. } \\
& H_{1}: \mu_{1} \neq \mu_{2} \quad \text { Terdapat perbedaan kemampuan awal koneksi matematis siswa antara } \\
& \text { yang menggunakan pembelajaran contextual teaching and learning (CTL) } \\
& \text { berbantuan software geogebra dengan yang menggunakan pembelajaran } \\
& \text { konvensional. }
\end{aligned}
$$

Adapun langkah yang dilakukan dalam analisis data pretes yaitu: yang pertama uji normalitas dengan menggunakan uji Shapiro Wilk. Nilai signifikansi kelas eksperimen yang diperoleh yaitu 0,142 lebih besar dari 0,05 artinya bahwa data pretes kemampuan koneksi matematis siswa kelas eksperimen berdistribusi normal. Begitu juga dengan nilai signifikansi kelas kontrol yaitu 0,056 lebih besar dari 0,05 artinya bahwa data pretes kemampuan koneksi matematis siswa kelas kontrol berdistribusi normal. Selanjutnya, dilakukan uji homogenitas dengan menggunakan uji Levene's diperoleh nilai signifikansi 0,714 lebih besar dari 0,05 artinya bahwa pretes kemampuan koneksi matematis siswa memiliki varians sama. Kemudian, karena data pretes kemampuan koneksi matematis berdistribusi normal dan homogen maka selanjutnya dilakukan uji perbedaan dua rerata atau uji two independent sample t-test equal variance assumed.

Tabel 3.

Hasil analisis data pretes kemampuan koneksi matematis

\begin{tabular}{cccc}
\hline Kelas & $\begin{array}{c}\text { Shapiro wilk } \\
\text { sig. }\end{array}$ & $\begin{array}{c}\text { Levene's test } \\
\text { sig. }\end{array}$ & $\begin{array}{c}\mathbf{t} \\
\text { sig. }\end{array}$ \\
\hline $\begin{array}{c}\text { Eksperimen } \\
\text { Kontrol }\end{array}$ & $\begin{array}{c}0,142 \\
0,56\end{array}$ & 0,714 & 0,150 \\
\hline
\end{tabular}

Berdasarkan Tabel 3 diperoleh informasi bahwa nilai signifikansi 0,150 lebih besar dari 0,05 sehingga $H_{0}$ diterima, artinya tidak terdapat perbedaan kemampuan awal koneksi matematis siswa antara yang menggunakan pembelajaran contextual teaching and learning (CTL) berbantuan software geogebra dengan yang menggunakan pembelajaran konvensional.

\section{N-Gain Kemampuan Koneksi Matematis}

Data peningkatan kemampuan koneksi matematis siswa diperoleh dari hasil pretes dan postes kemampuan koneksi matematis. Tabel 4 merupakan rangkuman deskripsi data $\mathrm{N}$-gain kemampuan koneksi matematis.

Tabel 4.

Deskripsi data $n$-gain kemampuan koneksi matematis

\begin{tabular}{ccccc}
\hline Kelas & $\mathbf{N}$ & Rata-Rata & Maks & Min \\
\hline Eksperimen & 25 & 0,83 & 1,00 & 0,43 \\
Kontrol & 26 & 0,66 & 1,00 & 0,33 \\
\hline
\end{tabular}

Selain menggunakan statistik deskriptif, pengolahan data $\mathrm{N}$-gain juga dilakukan menggunakan statistik inferensial. Hipotesis yang digunakan adalah:

$H_{0}: \mu_{1} \leq \mu_{2}$ Peningkatan kemampuan koneksi matematis siswa dengan menggunakan pembelajaran contextual teaching and learning (CTL) berbantuan software geogebra tidak lebih baik daripada siswa yang menggunakan pembelajaran konvensional. 
$\begin{aligned} H_{1}: \mu_{1}>\mu_{2} & \text { Peningkatan kemampuan koneksi matematis siswa dengan menggunakan } \\ & \text { pembelajaran contextual teaching and learning (CTL) berbantuan software } \\ & \text { geogebra lebih baik daripada siswa yang menggunakan pembelajaran } \\ & \text { konvensional. }\end{aligned}$

Langkah-langkah yang dilakukan dalam analisis data $N$-gain yaitu: yang pertama uji normalitas dengan menggunakan uji Shapiro Wilk. Nilai signifikansi kelas eksperimen yang diperoleh yaitu 0,059 lebih besar dari 0,05 artinya bahwa data $\mathrm{N}$-gain kemampuan koneksi matematis siswa kelas eksperimen berdistribusi normal. Begitu juga dengan nilai signifikansi kelas kontrol yaitu 0,381 lebih besar dari 0,05 artinya bahwa data $\mathrm{N}$-gain kemampuan koneksi matematis siswa kelas kontrol berdistribusi normal. Selanjutnya, dilakukan uji homogenitas dengan menggunakan uji Levene's diperoleh nilai signifikansi 0,261 lebih besar dari 0,05 artinya bahwa data $\mathrm{N}$-gain kemampuan koneksi matematis siswa memilki varians sama. Kemudian, karena data $\mathrm{N}$-gain kemampuan koneksi matematis berdistribusi normal dan homogen maka selanjutnya dilakukan uji perbedaan dua rerata menggunakan uji two independent sample t-test equal variance assumed diperoleh nilai signifikansi 0,006 . Karena uji yang dilakukan adalah satu pihak maka $\frac{1}{2} \times(p-$ value $)=0,003$ lebih kecil dari 0,05 sehingga $H_{0}$ ditolak, artinya peningkatan kemampuan koneksi matematis siswa dengan menggunakan pembelajaran contextual teaching and learning $(\mathrm{CTL})$ berbantuan software geogebra lebih baik daripada siswa yang menggunakan pembelajaran konvensional. Tabel 5 merupakan rangkuman hasil analisis data $\mathrm{N}$-gain kemampuan koneksi matematis.

\section{Tabel 5.}

Hasil analisis data $n$-gain

\begin{tabular}{cccc}
\hline Kelas & $\begin{array}{c}\text { Shapiro wilk } \\
\text { sig. }\end{array}$ & $\begin{array}{c}\text { Levene's test } \\
\text { sig. }\end{array}$ & $\begin{array}{c}\mathbf{t} \\
\text { sig. }\end{array}$ \\
\hline $\begin{array}{c}\text { Eksperimen } \\
\text { Kontrol }\end{array}$ & 0,059 & 0,261 & 0,003 \\
\hline
\end{tabular}

Berdasarkan hasil uji statistik yang telah dilakukan secara keseluruhan dapat disimpulkan bahwa peningkatan kemampuan koneksi matematis siswa yang menggunakan pembelajaran CTL berbantuan software geogebra lebih baik dari siswa yang menggunakan pembelajaran konvensional. Indikator kemampuan koneksi matematis yang digunakan dalam penelitian ini adalah indikator menurut Hanock (Yanti et.al, 2016) yaitu mengenali dan menggunakan koneksi antar topik matematika; koneksi antar disiplin ilmu lain; mengenali dan menggunakan matematika dengan keterkaitan di luar matematika (kehidupan sehari-hari).

Permasalahan yang diberikan untuk mengukur indikator mengenali dan menggunakan koneksi antar topik matematika disajikan berikut.

Permasalahan:

Diketahui perbandingan dua panjang rusuk kubus $A$ dan kubus $B$ adalah $1: 3$. Volume kubus $A$ adalah $120 \mathrm{~cm}^{3}$. Tentukan volume kubus $\mathrm{B}$.

Jawaban yang diberikan siswa untuk permasalahan tersebut adalah siswa mampu mengenali dan menggunakan koneksi antar topik matematika. Hal tersebut ditunjukkan dengan siswa dapat menuliskan diketahui dan ditanyakan dari soal yang diberikan dengan tepat, selain itu siswa juga mampu melakukan perhitungan dengan benar yaitu ditandai dengan siswa mampu menuliskan ideide matematika mengenai perhitungan perbandingan lalu siswa juga dapat menuliskan kesimpulan dengan benar yang didalamnya menuliskan satuan dari volume juga. Gambar 1 merupakan jawaban benar yang diberikan siswa pada kelas eksperimen untuk indikator mengenali dan menggunakan koneksi antar topik matematika. 


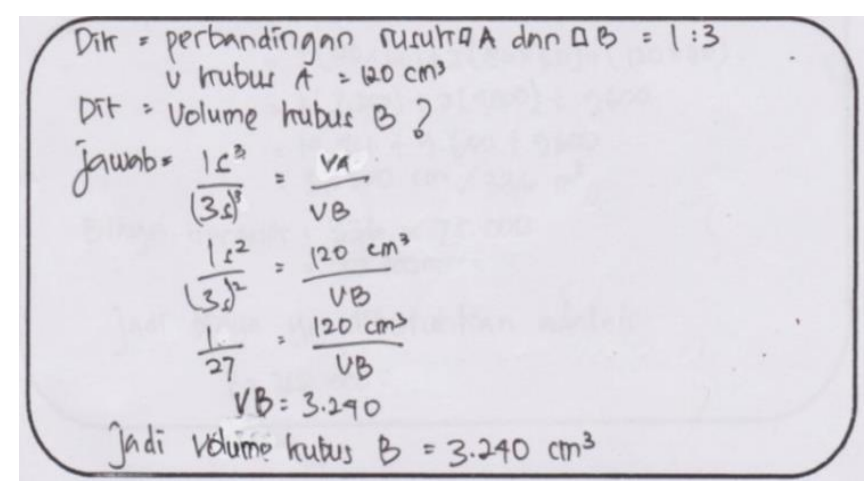

Gambar 1. Jawaban siswa 1

Selanjutnya jawaban yang berbeda diberikan oleh siswa kelas eksperimen pada indikator mengenali dan menggunakan koneksi antar topik matematika yang ditampilkan pada Gambar 2. Pada gambar tersebut terlihat bahwa siswa belum tepat dalam mengerjakan soal. Jawaban tersebut menunjukkan siswa itu mampu mengenali dan menggunakan koneksi antar topik matematika ditandai dengan siswa dapat menuliskan diketahui dan ditanyakan dari soal, siswa juga mampu melakukan perhitungan dengan benar namun siswa belum menuliskan satuan dari volume yang sesuai.

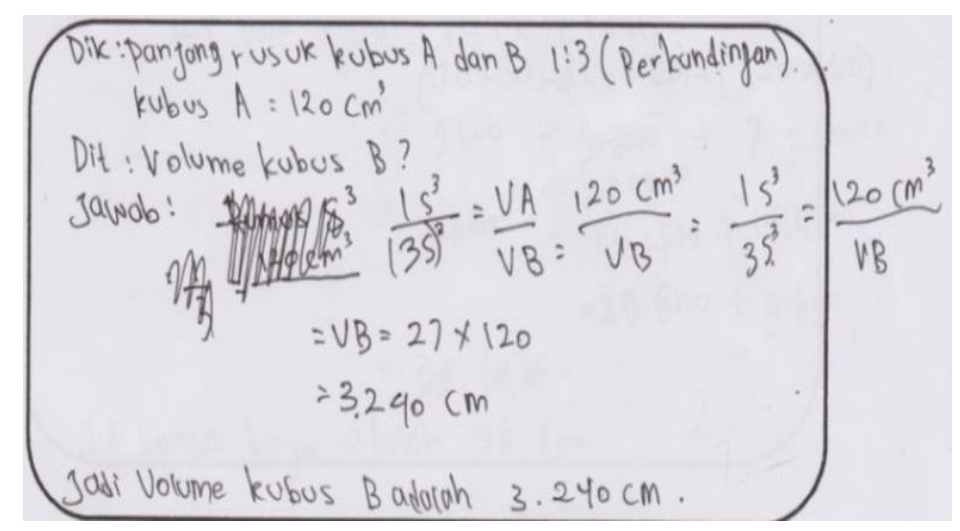

Gambar 2. Jawaban siswa 2

Peningkatan kemampuan kemampuan koneksi matematis siswa yang menggunakan pembelajaran CTL bebantuan software geogebra lebih baik dibandingkan dengan siswa yang menggunakan pembelajaran konvensional dikarenakan pada pembelajaran CTL berbantuan software geogebra terdapat langkah yang dapat membantu siswa menemukan ide-ide matematikanya dari tampilan model berupa gambar yang ada di dalam software geogebra. Temuan-temuan ide-ide matematika yang dapat ditampilkan dalam software geogebra akan dapat membantu siswa menerapkannya ke dalam kehidupan sehari-hari. Kegiatan tersebut merupakan indikator dari kemampuan koneksi matematis yaitu siswa dapat mengenali dan menggunakan koneksi antar topik matematika serta menerapkannya dalam kehidupan sehari-hari. Hal tersebut sesuai dengan NCTM (2000) yang menyatakan bahwa siswa akan dapat menerapkan pembelajaran yang didapatnya ke dalam kehidupan sehari-hari ketika siswa mampu memahami dan menemukan ide-ide matematika.

Penggunaan software geogebra dalam penelitian ini dapat membantu siswa dalam memahami materi bangun ruang kubus dan balok, karena pemanfaatan software geogebra dalam penelitian ini sebagai alat bantu visualisasi dari masalah kontekstual. Hal tersebut sejalan dengan pendapat Hohenwarter \& Fuchs (2004) dan Amam et.al (2017) yang menyatakan bahwa salah satu fungsi dari software geogebra adalah sebagai media demonstrasi dan visualisasi. Mengingat fungsi tersebut bahwa dalam pembelajaran CTL berbantuan software geogebra siswa mampu mengidentifikasi masalah dari model gambar yang ditampilkan dalam software geogebra kemudian siswa mengumpulkan ide-ide matematikanya lalu menemukan konsep-konsep matematika sehingga siswa mampu menerapkannya ke dalam kehidupan sehari-hari. 


\section{KESIMPULAN}

Berdasarkan analisis data, maka dapat diperoleh kesimpulan bahwa peningkatan kemampuan koneksi matematis siswa dengan menggunakan pembelajaran contextual teaching and learning (CTL) berbantuan software geogebra lebih baik daripada siswa yang menggunakan pembelajaran konvensional. Peningkatan kemampuan koneksi matematis siswa kelas eskperimen berada dalam kategori baik berdasarkan tabel kriteria $\mathrm{N}$-gain.

\section{REKOMENDASI}

Pembelajaran CTL berbantuan software geogebra dapat dijadikan sebagai salah satu alternatif pembelajaran matematika untuk meningkatkan kemampuan koneksi matematis siswa. Selain itu, untuk penelitian selanjutnya dapat mengaplikasikan pembelajaran ini dalam tingkatan siswa atau pada materi yang berbeda.

\section{UCAPAN TERIMA KASIH}

Penulis menyampaikan ucapan terima kasih kepada: Program Studi Pendidikan Matematika Universitas Galuh Ciamis yang telah memfasilitasi penulis melaksanakan kegiatan penelitian; Ibu Nur Eva Zakiah, M.Pd., dan Bapak Asep Amam, M.Pd., yang telah berkontribusi dan membimbing penulis dalam melaksanakan penelitian, sehingga penelitian berjalan dengan lancar dan tepat waktu; dan kepada kepala sekolah serta guru mata pelajaran matematika di MTs Negeri 1 Ciamis yang telah mengizinkan peneliti melaksanakan penelitian.

\section{DAFTAR PUSTAKA}

Amam, A. (2017). Penilaian kemampuan pemecahan masalah matematis siswa SMP. Teorema: Teori dan Riset Matematika, 2(1), 39-46.

Amam, A., Fatimah, A. T., Hartono, W., \& Effendi, A. (2017). Mathematical understanding of the underprivileged students through geogebra. Journal of Physics: Conference Series, 895(1), p. 012007, IOP Publishing.

Hohenwarter \& Fuchs. (2004). Combination of dynamic geometry, algebra and calculus in the software system geogebra.

Musriliani, C., Marwan, M., \& Ansari, B. I. (2015). Pengaruh pembelajaran contextual teaching learning (ctl) terhadap kemampuan koneksi matematis siswa smp ditinjau dari gender. Jurnal Didaktik Matematika, 2(2).

NCTM. (2000). Principles and Standards for School Mathematics.

Peraturan Menteri Pendidikan dan Kebudayaan Republik Indonesia Nomor 58 tahun 2014 yaitu tentang Tujuan Pembelajaran Matematika. [Online] Tersedia: https://www.slideshare.net/MuhammadAlfiansyah1/tujuan-pembelajaran-matematikaberdasarkan-peraturan-menteri-pendidikan-dan-kebudayaan-republik-indonesia-nomor-58tahun-2014

Sunaryo, Y., dan Fatimah, A. T. (2019). Pendekatan kontekstual dengan scaffolding untuk meningkatkan kemampuan berpikir kritis matematis. JNPM: Jurnal Nasional Pendidikan Matematika, 3(1), 66-79.

Zakiah, N. E. (2017). Pembelajaran dengan pendekatan kontekstual berbasis gaya kognitif untuk meningkatkan kemampuan metakognitif siswa. Pedagogy, 2(2), 11-29, ISSN 2502-3802.

Zakiah, N. E., Sunaryo, Y., \& Amam, A. (2019). Implementasi pendekatan kontekstual pada model pembelajaran berbasis masalah berdasarkan langkah-langkah polya. Teorema: Teori dan Riset Matematika, 4(2), 111-120, p-ISSN 2541-0660, e-ISSN 2597-7237. 